\title{
Products, Brands and Countries: Country-of- Brand (COB) and Product-of-Country (POC) Constructs in Country-of-Origin Research
}

\author{
N. Meltem Çakıcı" \\ Okan University
}

\begin{abstract}
Country of origin research in cross-cultural marketing has been criticised due to its varying operationalizations. One group of researchers has considered country of origins as the countries that are the origins of brands, while others have assumed that they represent the widely known countries that offer high quality products. In other words, the association of country of origin either with products or with brands and a lack of a clear conceptualization have caused confusion among researchers. This paper aims to suggest newly developed constructs such as "country-of-brand" and "product-of-country" that can be used instead of country of origin variable in future studies. Thus, the factor that is measured can be better explained. Additionally, the other factors that influence consumers' foreign product purchases are explained and a conceptual model is developed.

Keywords: country-of-origin, country-of-brand, product-of-country, country recognition accuracy.

\section{Ürünler, Markalar ve Ülkeler: Orijin Ülke Araştırmalarında Markanın Ülkesi ve Ülkenin Ürünü Kavramları}

\section{Özet}

Uluslararası pazarlamada orijin ülke hakkında yapılan araştırmalar, bu kavramın neyi temsil ettiğinin net bir şekilde ortaya konulmaması ve kavrama farklı açılardan bakılması nedeniyle eleştirilmektedir. Çalışmaların bazılarında orijin ülke bir markanın ait olduğu ülke anlamına gelirken, diğer çalışmalarda ise orijin ülke belirli ürünlerde kaliteyi sağlayarak dikkat çeken ülkelerle ilişkilendirilmektedir. Başka bir ifadeyle, orijin ülke, bazı çalışmalarda ürünlerle ülkeler arasında bağlantı kurarken diğer çalışmalarda ise markaları temsil etmekte ve bu durum kavram karmaşıklı̆g 1 yaratmaktadır. Bu çalışmanın amacı, gelecekteki çalışmalarda orijin ülke değişkeni yerine kullanılabilecek "markanın ülkesi” ve "ülkenin ürünü" kavramlarını sunarak ölçülmeye çalışılan faktörü daha açıklayıcı bir şekilde ortaya koymaya katkıda bulunmaktır. Ayrıca tüketicilerin yabancı ürün satın almalarına etki eden diğer faktörler açıklanarak kavramsal bir model geliştirilmiştir.
\end{abstract}

Anahtar kelimeler: orijin ülke, markanın ülkesi, ülkenin ürünü, ülke teşhisinin doğruluğu.

* N. Meltem Çakıcı is an Assistant Professor of Marketing in the Department of Business Administration at Okan University, 34959, Tuzla, İstanbul, Turkey. E-mail: meltem.cakici@okan.edu.tr 
$\mathrm{P}$ revious studies have found that consumers' product evaluations and buying intentions are related to the origins of the products (Papadopoulos and Heslop, 2002). These country-of-origin (hereafter referred to as COO) studies support the view that a product's origin affects consumers' perceptions, attitudes and purchase behavior (Bilkey and Nes, 1982; Johansson et al., 1985; Özsomer and Çavuşgil, 1991; Baughn and Yaprak, 1993; Gürhan-Canlı and Maheswaran, 2000; Papadopoulos and Heslop, 2003). However, COO research in cross-cultural marketing has been criticised due to several reasons. The use of products and brands interchangeably in certain studies and a lack of a clear conceptualization of $\mathrm{COO}$ have caused misunderstandings and confusion among researchers. One group of researchers has considered COOs as the countries that are the origins of brands while others have assumed that COOs represent the widely known places that offer high quality products (Josiassen et al., 2008; Samiee, 2011).

Various constructs (i.e. the main factors that are related to studying the effects of $\mathrm{COO}$ on consumer behavior) have been developed with an identifying acronym for each (see the list of acronyms in Table 1 in the Appendix). Originally, COO was named as "CO" (Samiee, 2011) and its image became the "COO image" (Josiassen et al., 2008). Consumers' perceptions of countries' products in a particular category were measured by constructs such as "product category image (hereafter referred to as PCATI)" (Diamantopoulos et al., 2011), and "product country image (hereafter referred to as PCI)" (Magnusson et al., 2011a). PCATI reflects consumers' COO assessments at the specific product category level (Diamantopoulos et al., 2011). Another category of constructs has been used for the investigation of the relationship between brands and their COOs. Country image (hereafter referred to as CI) (Roth and Romeo, 1992; Diamantopoulos et al., 2011) represents consumers' perception of products from a particular country based on their previous assessments of the country's marketing strengths and weaknesses. CI reflects consumers' COO assessments at the overall country level (Diamantopoulos et al., 2011). In other words, Diamantopoulos et al. (2011) measured consumers' assessments of brands' origins by the CI construct. Samiee (2011), on the other hand, used brand origin (hereafter referred to as BO) as the construct that links $\mathrm{COO}$ and origin of a brand. "BO is associated with a single country, and therefore, offers greater clarity if such a brand-relevant cognitive structure actually exists" (Samiee, 2011: 474).

"PCI of perceived COO" (Magnusson et al., 2011a) was developed as a new construct, defined as "the place-related images of the brand's perceived home country." It was measured by matching each respondent's brand origin perception with the associated product-category country image" (Magnusson et al., 2011a). Magnusson et al. (2011a) stated that this new construct represents an important shift in the conceptualization and subsequent operationalization of PCI since previous COO research had considered PCI only as image of a brand's home country without taking into account how the item is perceived (Papadopoulos and Heslop 2003; Magnusson et al., 2011a). In short, brand origin was conceptualized as "perceived COO" by Magnusson et al. (2011a), "CI" by Diamantopoulos et al. (2011) and "BO" by Samiee (2011). Other scholars also used concepts such as a brand's COO or country origin of a brand. These differing aspects have both enlarged the area of the research and at the same time added confusion in the results. 
When consumers are asked to evaluate products or product categories and specific countries' images for these (without considering their brand names), they combine the products and countries and make associations between these. Thus, the construct that will be used for the measurement of this association should represent both the products and the countries. For this reason, product-of-country (hereafter referred to as POC) will be used by the author as the construct which measures consumers' product-country associations in this study. In short, POC will represent "X product" of "Y country". POC can be used for a consideration of products and countries together; therefore the use of "origin" in the abbreviation does not make sense since the focus here is on the products and their widely known countries. In other words, countries are considered as "popular" for the related product category rather than as "origins" of these products.

On the other hand, when consumers are asked to evaluate brands and countries as origins of brands, then consumers think about brands and countries together and make associations between these. Thus, the construct that will be used for the measurement of this association should represent both brands and countries as origins. For this reason, country-of-brand (hereafter referred to as $\mathrm{COB}$ ) will be used by the author as the construct which measures consumers' brand-country associations in this study. COB will represent "Y country" of "Z brand". Brand origin is the country a brand is associated with or the headquarters of where the brand's owner is perceived to be located, regardless of where it is manufactured (Thakor and Lavack, 2003). COB, in this sense, represents the consideration of the country a brand is associated with and therefore can be used as the construct for an examination of brand origin effects. Usunier (2011) used "the progressive replacement of $C O O$ and $C O M$ by $C O B$ " as the subtitle in his paper but preferred to use BO afterwards for the origins of brands.

The objective of this study is to suggest the newly developed constructs such as $\mathrm{COB}$ and POC that can be used for more clarity instead of the general COO construct in future studies. The factor that is to be measured can be better explained by using these constructs. Alternatively, the accuracy of country recognition and the crucial factors influencing consumers' purchase of foreign products are offered within a new conceptual model to be studied empirically.

\section{Conceptual Model and Propositions}

$\mathrm{COO}$ as image of actual manufacturing origin based on "made-in" labels no longer holds (Usunier, 2011; Magnusson et al., 2011b). Given the rise of global branding and corporations' use of multiple countries for sourcing components, manufacturing and assembling products (Johansson and Nebenzahl, 1986; Han and Terpstra, 1988; Häubl, 1996), "CO has essentially lost its validity as an important issue with a managerial relevance" (Samiee, 2011, p.473). Consumers still perceive product cues related to origin but manufacturing origin has become largely irrelevant (Samiee et al., 2005; Usunier, 2006; Samiee, 2011), and at the same time brands have progressively taken the lead in suggesting product origin. Consumers do not need to spend much effort since a brand is clearly displayed and it is a visually salient cue (Usunier, 2011). It is difficult to realisti- 
cally attribute the production of a particular product to a single country. Brand origin, on the other hand, is associated with a single country, and therefore, offers greater clarity. Given that firms source their products for global markets from multiple locations, brand origin is the only stable information about a product. COO should not be conceptualized as a construct that is only a driver of product image, and therefore is associated with product category images, but also it is a driver of brand image (Diamantopoulos et al., 2011). For this reason, the use of COB rather than COO makes more sense.

In $\mathrm{COB}$ studies, responses to outcome variables such as buying intentions and actual purchases should be obtained on the basis of COBs identified by the respondents (whether correct or incorrect) rather than by the researchers. During the examination of the potential transfer of country image association to brand evaluations and behavioral outcomes, researchers should recognize that not all respondents may associate the brand with the correct $\mathrm{COO}$ (the accurate $\mathrm{COB}$ ). Researchers' presenting respondents with both a list of brands and a list of associated countries compromises the validity of empirical results (Balabanis and Diamantopoulos, 2008). Biasing respondents by mentioning country names is a key shortcoming in COB research (Samiee, 2011). It may be fruitful to try to determine the influence of the perceptions of the brand origin on actual buying behavior separately from brand attitude (Magnusson et al., 2011a). Past research has clearly found that $\mathrm{COB}$ has the strongest effect on quality evaluations, followed by brand attitude, and the weakest effect on purchase intentions (Verlegh and Steenkamp, 1999). It has been shown that purchase intention measures are imperfect predictors of behavior (Chandon et al., 2005), and that there are many contextual factors that can prevent consumers from behaving in an intended way. For this reason, the impact of COB on consumers' actual purchase behavior rather than their intentions should be examined. Thus;

\section{$P_{I}$ : COB influences consumers' purchase of foreign products.}

The impact of COB on consumers' evaluation of products may also be influenced by that country's image in terms of the products that are evaluated by consumers. Past research has found that POC perceptions are linked to product evaluations such as product quality and credibility (Hong and Wyer, 1990; Leclerc et al., 1994; Thakor and Lavack, 2003), and to attitudes and purchase intentions (Knight and Calantone, 2000; Parameswaran and Pisharodi, 2002; Aaker, 2004). For example, consumers may have knowledge about specific countries which have been popular in terms of certain product categories such as cars, technology, cosmetics or textile. They may develop a positive or negative attitude toward a product by taking into account only the POC dimension - without consideration of its brand- which means that whether the country is superior or not in that product category is considered. In other words, consumers consume products of these countries just because of these countries' popularity in the relevant product categories. For instance, some countries are known as superior in specific product categories such as German machinery and French wine (Samiee, 2011). Thus;

$P_{2}:$ POC influences consumers' purchase of foreign products. 
On the other hand, consumers make associations between brands, product categories and countries if they consider COB and POC together. For instance, COB may positively influence consumers if they have positive attitudes toward that country's products. In other words, consumers may evaluate the origin of a brand (COB) based on their assessment of the same country that is well known for offering a specific product type with high quality (POC). Hence;

$P_{3}:$ POC moderates the impact of $\mathrm{COB}$ on consumers' purchase of foreign products.

Brand knowledge represents the personal meaning about a brand that consumers have stored in memory; it includes all descriptive and evaluative brand-related information (Keller, 2003a). Such knowledge can be given by marketers in order to link brands with positive country images, or it can be acquired by consumers independently of marketers' actions such as marketplace experiences, word-of-mouth advertising, or brand information acquisition. Irrespective of the source, for any given brand, consumers may or may not know a brand's origin or may even confuse the brand as being from a country other than its actual origin.

There have been opposing arguments about the effects of COB and accuracy in consumers' identification of brand origins on their evaluations of products and purchase behavior. A brand origin recognition accuracy (hereafter referred to as BORA) construct was conceptualized, measured and tested by Samiee et al. (2005); they concluded that the effects of COB on consumers' product judgments had been exaggerated. Samiee et al. (2005, p.392) questionned the assumption that consumers actually know or seek the origins of brands when forming judgments and making purchase decisions. "Consumers either have limited recognition of brand origins or find such information relatively unimportant and thus unworthy of retention in memory." Balabanis and Diamantopoulos (2008) supported Samiee et al.'s (2005) conclusion after their investigation of consumers' ability to classify correctly different brands within a specific product category according to their COBs. They concluded that the consumers' overall ability to identify COB was limited. On the other hand, Magnusson et al. (2011b), in this context, did not agree with the conclusions of the previous studies that the influence of COB has been inflated (Samiee et al., 2005) and that therefore COB has become an irrelevant construct in marketing (Usunier, 2006). Magnusson et al. (2011a) suggested that the consumers' perceived $\mathrm{COO}$ of a brand (COB), regardless of its accuracy, affects brand attitude. "... accurate COO knowledge is not a prerequisite for COO to affect brand attitude" (Magnusson et al., 2011a, p.466). Magnusson et al. (2011a) also acknowledged that they found significant changes in brand attitude after informing respondents of a brand's actual home country. At this point, Usunier (2011) argued that accuracy matters if it is found that attitude toward brand changes after the respondents learn the actual (correct) $\mathrm{COB}$ and compare it with their perceived (incorrect) $\mathrm{COB}$.

The author of this paper argues that the contradictory arguments of the scholars about the effect of COB on consumers' attitudes are due to the fact that $\mathrm{COB}$ itself is a multidi- 
mensional construct and includes multiple factors each of which has an effect on consumers. In COB research, it is never clear what is being measured, whether it is country image, product image, or consumer attitude because "origin image is an intersection construct; $a$ crossroad concept between countries, products, and consumers." (Usunier, 2011, p.486). Magnusson et al. (2011a) suggested that consumers are influenced by COB even if they have incorrect information about the actual origins of brands. The focus of their study is to provide evidence that the $\mathrm{COB}$ effects on consumers should not be ignored. Usunier (2011) takes into account the interaction of correct/incorrect COB classification with association favorability and states that companies with incorrectly classified COBs and unfavorable association should promote correct classification if correct $\mathrm{COB}$ classification results in a positive change in terms of association favorability. In other words, a shift from unfavorable association to favorable association is possible by providing correct COB classification. Accuracy, in this sense, benefits the company and can be considered important for the success of the brand in the market. In short, Magnusson et al. (2011a) did not state that inaccuracy and accuracy of COB knowledge have the same effects on consumers' attitudes and that no effort should be made to replace inaccuracy with accuracy. They just emphasized that the characteristic of the COB knowledge (accurate or inaccurate) does not eliminate the impact of COB on consumers. Usunier (2011), on the other hand, concentrates on the importance of the accuracy of the consumers' knowledge of origin by taking into account its joint effect with favorability. This means that Usunier (2011) considers the COB effect important when it is considered with knowledge accuracy and stresses the importance of further research on the causes of correct or incorrect identification of brand origin by consumers. In this paper, several scenarios are developed in order to offer suggestions at this point. Suppose that country $\mathrm{X}$ is the correct origin of a brand. The following scenarios are possible:

Scenario 1: A consumer has "correct" knowledge about the origin of the brand (country X). This consumer thinks that products from country $\mathrm{X}$ are of good quality. It means that she/he has "positive" attitudes towards POC. Thus, POC has a positive impact on the consumer's purchase of foreign products.

Scenario 2: A consumer has "incorrect" knowledge about the origin of the brand. In other words, she/he thinks that country $\mathrm{Y}$ is the correct origin. This consumer also thinks that products from country Y are of good quality. This means that she or he has "positive" attitudes towards POC. Thus, POC has a positive impact on the consumer's purchase of foreign products.

Scenario 3: A consumer has "correct" knowledge about the origin of the brand (country X). This consumer thinks that products from country $\mathrm{X}$ are not of good quality. This means that she/he has "negative" attitudes towards POC. Thus, POC has a negative impact on the consumer's purchase of foreign products.

Scenario 4: A consumer has "incorrect" knowledge about the origin of the brand. In other words, she/he thinks that country $\mathrm{Y}$ is the correct origin. This consumer also thinks that products from country Y are not of good quality. This means that she/he has "negative" attitudes towards POC. Thus, POC has a negative impact on the consumer's purchase of foreign products. 
In brief, the accuracy of $\mathrm{COB}$ knowledge influences consumers' purchase of foreign products through POC; if attitude towards POC is positive/negative, then accuracy or inaccuracy of $\mathrm{COB}$ knowledge positively/negatively influences the consumers' purchase of foreign products. Thus;

$P_{4}:$ POC mediates the effect of consumers' accurate or inaccurate classification of $C O B$ on their purchase of foreign products.

Samiee et al. (2005) stated that product type influences the effect of COB on consumers' purchase decisions. COB information may be highly important for consumers while choosing an automobile or a technological product since COB provides additional information about the quality and other purchase-relevant features of these products. However, for frequently purchased and packaged goods, COB may not affect consumers' decision making since it is less likely that country superiority is attached to these product categories. Therefore,

$P_{5}:$ Product type moderates the impact of $C O B$ on consumers' purchase of foreign products.

Product familiarity refers to how familiar a consumer is with a given product category (Josiassen et al., 2008). The studies on the effect of COB on consumers' decision making describe $\mathrm{COB}$ as a "halo" that consumers use while evaluating a product that they are unfamiliar with (Bilkey and Nes, 1982; Li et al., 2000; Insch and Mcbride, 2004). They do this when they have little direct knowledge of the product itself (Laroche et al., 2005). This means that COB is important for consumers' evaluation of products when their product familiarity is low and the origin of the brand can give insight about the products' benefits. Josiassen et al. (2008) conclude in their study that consumers consider $\mathrm{COB}$ to be more important for their product evaluations when they are less familiar with the product category. This means that their results indicate a halo effect. In contrast, if consumers' familiarity with the product is high, they rely less on COB in their evaluation (Huber and McCann, 1982) since they have already gained information or had experience with the products. Hence;

$P_{6}:$ The impact of $C O B$ on consumers' purchase of foreign products is high/ low if consumers are unfamiliar/familiar with the product category.

Consumers go through either a central or a peripheral route to persuasion based on the Elaboration Likelihood Model (ELM) (Petty and Cacioppo, 1984). Consumers use a peripheral route under low involvement conditions and evaluate products based on clear and readily accessible cues. Some of the COB studies (Han, 1989; Maheswaran, 1994) suggest that the $\mathrm{COB}$ cue has these characteristics which means that consumers can easily get information about COB. Josiassen et al. (2008) concluded in their study that $\mathrm{COO}$ was used as a salient cue by consumers; consumers consider $\mathrm{COB}$ to be more important for their evaluations when they are less involved with the products that they are evaluating. Thus;

$P_{7}:$ The impact of $C O B$ on consumers' purchase of foreign products is high/ low if consumers have low/high involvement with the products. 
Consumers naturally possess both positive and negative biases toward countries for reasons entirely unrelated to the products or brands being examined such as history, culture, language, politics and the like (Balabanis et al., 2001). This implies that researchers need to creatively develop ways of passively obtaining such information. Highly ethnocentric consumers focus more on origins of brands, and the COB information is more diagnostic for these consumers (Shimp and Sharma, 1987). Cosmopolitan consumers prefer to consume different types of products and brands from different countries, and the origins of brands do not play big roles in their evaluation of products. Cosmopolitans perceive themselves as more international (Hannerz, 1990) and more responsive to global consumer culture positioning strategies (Alden et al., 1999). Thus, they are more likely to adopt products from other cultures and places. Therefore;

$P_{8}:$ The impact of $C O B$ on consumers' purchase of foreign products is high/ low for consumers with high/low ethnocentrism.

$P_{9}:$ The impact of $C O B$ on consumers' purchase of foreign products is influenced by the cosmopolitan orientation of consumers.

The conceptual model (Figure 1) shows the independent, moderating, mediating and dependent variables of this study that are suggested for more empirical research. The main purpose is to understand the effects of several variables on the purchase behavior of consumers so that the study can fill in the gap caused by the multiple studies' focus on attitudes, perceptions or intentions rather than on the purchase behavior itself.

Figure 1:

\section{Conceptual Modal}

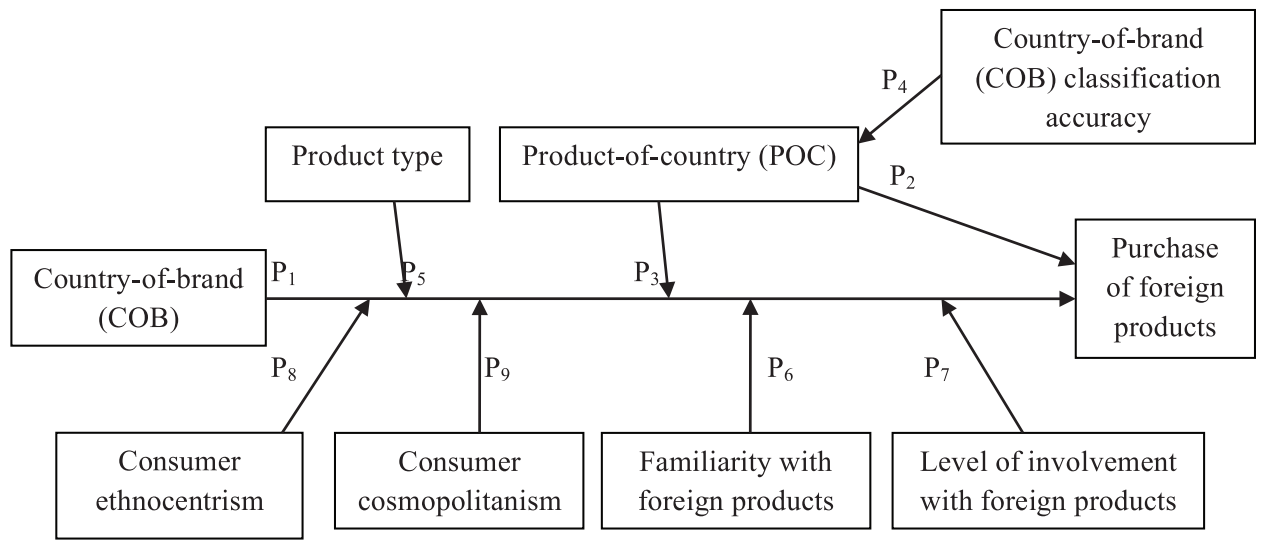

\section{Conclusion}

Consumers' evaluations and purchases of foreign products are influenced by several product-, country-, and/or consumer-specific characteristics such as ethnocentric or 
cosmopolitan orientation, familiarity and involvement with foreign products, and category of the foreign product. On the other hand, country origins of products and brands have been considered as important factors that affect consumers' evaluations and purchases. The challenge in the analysis of countries as origins occurs from the use of $\mathrm{COO}$ within multiple contexts that relates this construct either to products (and their made-in origins) or to brands. Adopting this perspective leads to a confusion among researchers since products, brands and countries are interrelated and it is difficult to disentangle their separate from their joint effects.

This study proposes "POC" and "COB" as the constructs that can be used for the examination of country origin effects. POC refers to X product of $Y$ country and can be used for consumers' product-country associations. The use of "origin" in the abbreviation does not make sense since the focus here is on the products and the countries that are widely known as offering high quality products. In other words, countries are considered as "popular" for a product category rather than as "origins" for these products. The use of POC for this purpose can handle the challenge of defining the role of a country that is expected to affect consumers when $\mathrm{COO}$ construct is used alone or together with a product or a brand such as "a product's COO" or "a brand's COO". POC construct will be representative of the high-quality products that have been offered by certain countries.

COB refers to $\mathrm{Y}$ country of $\mathrm{Z}$ brand and can be used for consumers' brand-country associations. When consumers are asked to evaluate brands and countries as origins of brands, then consumers think about brands and countries together and make associations between these. COB represents the country a brand is associated with and therefore can be used as the construct for examination of brand origin effects. Just like the contribution of POC, COB can clearly demonstrate the role -origin of a brand- of the country that is meant to influence consumers' purchase behavior.

Consumers' correct or incorrect classification of COB also influences their purchase of foreign products and this is through the impact of POC. Suppose that the correct $\mathrm{COB}$ is $\mathrm{X}$ and a consumer classifies it as $\mathrm{Y}$. This consumer also thinks that products from country Y (POC) are not of good quality. This means that she/he has negative attitudes towards POC. Therefore, this consumer's incorrect classification of COB (as $\mathrm{Y}$ ) leads to an unfavorable perception of POC (products from country Y) which in turn will influence her/his purchase of foreign products negatively.

From a theoretical perspective, this study extends previous $\mathrm{COO}$ research by integrating several individual level variables with the newly developed constructs of "POC" and "COB" that are expected to influence consumers' foreign product purchases. Further research can empirically test this model and examine the impact of POC and COB on other factors and within different contexts.

It is also argued in this study that the use of the "origin country" as a tool for a marketing strategy requires an in-depth understanding of the factors that are associated with this dimension. Whether consumers relate a country as the origin of a brand or as the place that is reputable in terms of offering high quality products can make a big difference regarding the impact of a marketing campaign. Likewise, consumers may still consider origin as the manufacturing place of a product even if there has been 
an agreement among academicians about the crucial role of the brand and its origin. This is because consumers may not be knowledgable about the "made-in" country of a product. From a managerial perspective, foreign branding strategy, for example, should take into account the interdepence of a product and a brand and consumers' assocation of countries with multiple factors.

\section{References}

Aaker, D. (2004). "Leveraging the Corporate Brand," California Management Review, 46(3): 6-18.

Alden, D.L. Steenkamp, J.B.E.M., and Rajeev, B. (1999). "Brand Positioning Through Advertising in Asia, North America, and Europe: The Role of Global Consumer Culture," Journal of Marketing, 63 (January): 75-87.

Balabanis, G. and Diamantopoulos, A. (2008). "Brand Origin Identification by Consumers: A Classification Perspective," Journal of International Marketing, 16(1): 39-71.

Balabanis, G., Diamantopoulos, A., Mueller, R.D., and Melewar, T.C. (2001). "The Impact of Nationalism, Patriotism and Internationalism on Consumer Ethnocentric Tendencies," Journal of International Business Studies, 32(1): 157-175.

Baughn, C. and Yaprak, A. (1993). "Mapping Country-of Origin Research - Recent Devel-opments and Emerging Avenues," in N. Papadopoulos and Heslop, L.A. (eds.), Product-Country Images: Impact and Role in International Marketing: 89-115. New York: Inter-national Business Press.

Bilkey, W.J. and Nes, E. (1982). "Country-of-Origin Effects on Product Evaluations,"Journal of International Business Studies, 13(1): 89-100.

Chandon, P., Morwitz, V., and Reinartz, W. (2005). "Do Intentions Really Predict Behaviour? SelfGenerated Validity Effects in Survey Research," Journal of Marketing, 69(2): 1-14.

Diamantopoulos, A., Schlegelmilch, B, and Palihawadana, D. (2011). "The Relationship Between Country-of-Origin Image and Brand Image as Drivers of Purchase Intentions: A Test of Alternative Perspectives," International Marketing Review, 28(5): 508-524.

Gürhan-Canl1, Z. and Maheswaran, D. (2000). "Determinants of Country-of-Origin Evaluations," Journal of Consumer Research, 2(1): 96-108.

Han, C.M. and Terpstra, V. (1988). "Country-of-Origin Effects for Uni-National and Bi-National Products," Journal of International Business Studies, 19(2): 235-255.

Han, C.M. (1989). “Country Image: Halo or Summary Construct?," Journal of Marketing Research, 26(2): 222-229.

Hannerz, U. (1990). "Cosmopolitans and Locals in World Culture," Theory, Culture, and Society, $7(2 / 3): 237-251$.

Häubl, G. (1996). "A Cross-National Investigation of the Effects of Country of Origin and Brand Name on the Evaluation of a New Car," International Marketing Review, 13(5): 76-97.

Hong, S.-T., and Wyer, R.S. (1990). "Determinants of Product Evaluation: Effects of the Time Interval between Knowledge of a Product's Country of Origin and Information About Its Specific Attributes," Journal of Consumer Research, 17: 277-288.

Huber, J. and McCann, J. (1982). “The Impact of Inferential Beliefs on Product Evaluations," Journal of Marketing Research, 19: 324-333. 
Insch, G.S. and McBride, J.B. (2004). "The Impact of Country-of-Origin Cues on Consumer Perceptions of Product Quality: A Binational Test of the Decomposed Country-of-Origin Construct," Journal of Business Research, 57(3): 256-265.

Johansson, J.K., Douglas, S.P., and Nonaka, I. (1985).“Assessing the Impact of Country of Origin on Product Evaluations: A New Methodological Perspective,"Journal of Marketing Research, 22(4): 388-396.

Johansson, J.K. and Nebenzahl, I.D. (1986), "Multinational Expansion: Effect on Brand Evaluations," Journal of International Business Studies, 17: 101-126.

Josiassen, A., Lukas, B.A., and Whitwell, G.J. (2008). "Country-of-Origin Contingencies: Competing Perspectives on Product Familiarity and Product Involvement, International Marketing Review, 25(4): 423-440.

Keller, K.L. (2003a)."Brand Synthesis: The Multidimensionality of Brand Knowledge," Journal of Consumer Research, 29 (4): 595-600.

Knight, G.A. and Calantone, R.J. (2000). "A Flexible Model of Consumer Country-of-Origin Perceptions: A Cross-Cultural Investigation," International Marketing Review, 17(2): 127- 145.

Laroche, M., Papadopoulos, N., Heslop, L.A., and Mourali, M. (2005). "The Influence of Country Image Structure on Consumer Evaluations of Foreign Products," International Marketing Review, 22(1): 96-115.

Leclerc, F., Schmitt, B.H., and Dubé, L. (1994). "Foreign Branding and Its Effects on Product Perceptions and Attitudes," Journal of Marketing Research, 31(2): 263-270.

Li, Z.G., Murray, L.W., and Scott, D. (2000). "Global Sourcing, Multiple Country-of-Origin Facets, and Consumer Reactions," Journal of Business Research, 47(2): 121-133.

Magnusson, P., Westjohn, S.A., and Zdravkovic, S. (2011a). "What? I Thought Samsung Was Japanese: Accurate or Not, Perceived Country of Origin Matters," International Marketing Review, 28 (5): 454-472.

Magnusson, P. Westjohn, S.A., and Zdravkovic, S. (2011b). "Further Clarification on How Perceived Brand Origin Affects Brand Attitude: A Reply to Samiee and Usunier," International Marketing Review, 28(5): 497-507.

Maheswaran, D. (1994). "Country of Origin as a Stereotype: Effects of Consumer Expertise and Attribute Strength on Product Evaluations," Journal of Consumer Research, 21(2): 354-365.

Özsomer, A. and Çavuşgil, S.T. (1991). "Country-of-origin Effects on Product Evaluations: A Sequel to Bilkey and Nes' Review." Paper presented at the American Marketing Association Summer Educators' Conference, San Diego, CA.

Papadopoulos, N. and Heslop, L. (2002). "Country Equity and Country Branding: Problems and Prospects," Journal of Brand Management, 9(4/5): 294-314.

Papadopoulos, N. and Heslop, L.A. (2003), "Country Equity and Product-Country Images: Stateof-the-Art in Research and Implications," In S.C. Jain (ed.), Handbook of Research in International Marketing: 402-433. Edwar Elgar Publishing.

Parameswaran, R. and Pisharodi, R.M. (2002). "Assimilation Effects in Country Image Research," International Marketing Review, 19(3): 259-278.

Petty, R.E. and Cacioppo, J.T. (1984). "The Effects of Involvement on Responses to Argument Quantity and Quality: Central and Peripheral Routes to Persuasion," Journal of Personality and Social Psychology, 46(1): 69-81. 
Roth, M.S. and Romeo, J.B. (1992). "Matching Product Category and Country-of-Origin Effects," Journal of International Business Studies, 23(3): 447-497.

Samiee S., Shimp, T.A., and Sharma, S, (2005). "Brand Origin Recognition Accuracy: Its Antecedents and Consumers' Cognitive Limitations," Journal of International Business Studies, 36(4): 379-397.

Samiee, S. (2011). "Resolving the Impasse Regarding Research on the Origins of Products and Brands," International Marketing Review, 28(5): 473-485.

Shimp, T.A. and Sharma, S. (1987). "Consumer Ethnocentrism: Construction and Validation of the CETSCALE," Journal of Marketing Research, 24(8): 280-289.

Thakor, M.V. and Lavack, A.M. (2003). "Effect of Perceived Brand Origin Associations on Consumer Perceptions of Quality,” Journal of Product \& Brand Management, 12(6): 394-407.

Usunier, J.C. (2006). "Relevance in Business Research: The Case of Country-of-Origin Research in Marketing," European Management Review, 3(1): 60-73.

Usunier, J.C. (2011). "The Shift from Manufacturing to Brand Origin: Suggestions for Improving COO Relevance," International Marketing Review, 28(5): 486-496.

Verlegh, P.W.J. and Steenkamp, J.B.E.M. (1999). "A Review and Meta-Analysis of Country-of-Origin Research,” Journal of Economic Psychology, 20(5): 521-546. 


\section{Appendix}

Table 1

\section{List of Acronyms}

\begin{tabular}{|c|c|c|c|}
\hline Acronym & Source & Word(s) & Definition \\
\hline $\mathrm{CO}$ & Samiee, 2011 & $\begin{array}{l}\text { Country- } \\
\text { of-Origin }\end{array}$ & $\begin{array}{l}\text { "CO has been the traditional way of examining the influences } \\
\text { of a product's origin in which respondents are artificially } \\
\text { alerted to alternative production (or assembly) locations of a } \\
\text { product following which respondents ' perceptions of the product } \\
\text { following exposure to location cues are assessed. Given the } \\
\text { broad customer knowledge regarding multi-locational nature } \\
\text { of production and sourcing for components, sub-assemblies, } \\
\text { and finished products, it is difficult to realistically attribute the } \\
\text { production of a particular product to a single country, something } \\
\text { that research conditions often impose or ask." }\end{array}$ \\
\hline $\mathrm{BO}$ & Samiee, 2011 & $\begin{array}{l}\text { Brand } \\
\text { Origin }\end{array}$ & $\begin{array}{l}\text { "In contrast to } C O, B O \text { which is defined as the headquarters } \\
\text { location of the firm initiating a brand also offers the advantage } \\
\text { of greater stability over longer periods. BO is associated with } \\
\text { a single country and, therefore, offers greater clarity if such a } \\
\text { brand-relevant cognitive structure actually exists." }\end{array}$ \\
\hline PCATI & $\begin{array}{l}\text { Diamantopoulos } \\
\text { et al., } 2011\end{array}$ & $\begin{array}{l}\text { Product } \\
\text { Category } \\
\text { Image }\end{array}$ & $\begin{array}{l}\text { "PCATI captures the image of that country's products in a } \\
\text { particular category." “consumers' COO assessments at the } \\
\text { specific product category level." }\end{array}$ \\
\hline $\mathrm{CI}$ & $\begin{array}{l}\text { Diamantopoulos } \\
\text { et al., 2011; } \\
\text { Roth and } \\
\text { Romeo, } 1992\end{array}$ & $\begin{array}{l}\text { Country } \\
\text { Image }\end{array}$ & $\begin{array}{l}\text { "Country image is the overall perception consumers form } \\
\text { of products from a particular country, based on their prior } \\
\text { perceptions of the country's production and marketing strengths } \\
\text { and weaknesses." "consumers' COO assessments at the overall } \\
\text { country level." }\end{array}$ \\
\hline PCI & $\begin{array}{l}\text { Magnusson et } \\
\text { al., 2011a }\end{array}$ & $\begin{array}{l}\text { Product- } \\
\text { Country } \\
\text { Image }\end{array}$ & $\begin{array}{l}\text { "Traditional COO research has viewed PCI as the place-related } \\
\text { images of a brand's home country. We extend this construct by } \\
\text { making the perceptual aspect of "place-related associations" } \\
\text { explicit. Thus, we define PCI of perceived COO as the place- } \\
\text { related images of the brand's perceived home country. While } \\
\text { seemingly minor, this represents an important shift in the } \\
\text { conceptualization and subsequent operationalization of PCI." }\end{array}$ \\
\hline $\mathrm{COB}$ & $\begin{array}{l}\text { Developed in } \\
\text { this study }\end{array}$ & $\begin{array}{l}\text { Country- } \\
\text { of-Brand }\end{array}$ & $\begin{array}{l}\text { When consumers are asked to evaluate brands and countries } \\
\text { as origins of brands, then consumers think about brands and } \\
\text { countries together and make associations between these. } \\
\text { Thus, the construct that will be used for the measurement of } \\
\text { this association should represent both brands and countries as } \\
\text { origins. COB, in this sense, represents the consideration of the } \\
\text { country a brand is associated with and therefore can be used as } \\
\text { the construct for examination of brand origin effects. }\end{array}$ \\
\hline POC & $\begin{array}{l}\text { Developed in } \\
\text { this study }\end{array}$ & $\begin{array}{l}\text { Product- } \\
\text { of } \\
\text { Country }\end{array}$ & $\begin{array}{l}\text { POC can be used for consideration of products and countries } \\
\text { together and the use of "origin" in the abbreviation does } \\
\text { not make sense since the focus here is on the products and } \\
\text { their widely known countries. In other words, countries are } \\
\text { considered as "popular" for the related product category rather } \\
\text { than as "origins" of these products. }\end{array}$ \\
\hline
\end{tabular}

